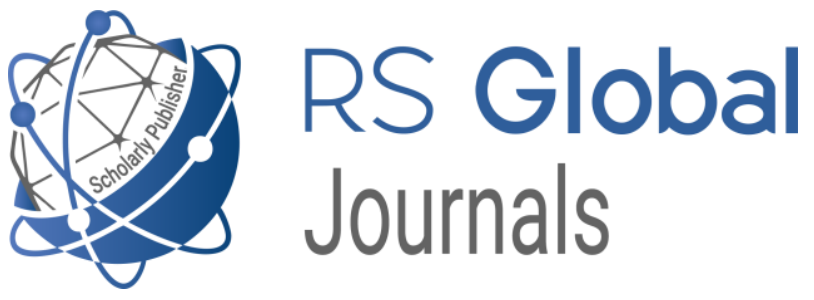

Scholarly Publisher

RS Global Sp. z O.O.

ISNI: 0000000484952390

Dolna 17, Warsaw, Poland 00-773

Tel: +48226022703

Email: editorial_office@rsglobal.pl

JOURNAL International Journal of Innovative Technologies in Social Science

p-ISSN $2544-9338$

e-ISSN

2544-9435

PUBLISHER

RS Global Sp. z O.O., Poland

ARTICLE TITLE

STRATEGY OF IMPLEMENTATION OF THE CONCEPT OF THE NATIONAL PROGRAM OF MILITARY-PATRIOTIC EDUCATION «HORTING-PATRIOT»

AUTHOR(S) Borodai Eduard Mykolayovych

Borodai E. M. (2020) Strategy of Implementation of the Concept of the National Program of Military-Patriotic Education «Horting-

ARTICLE INFO Patriot». International Journal of Innovative Technologies in Social Science. 7(28).

doi: 10.31435/rsglobal_ijitss/30122020/7290

DOI

https://doi.org/10.31435/rsglobal_ijitss/30122020/7290

RECEIVED

27 October 2020

ACCEPTED

08 December 2020

PUBLISHED

13 December 2020

LICENSE

This work is licensed under a Creative Commons Attribution

4.0 International License.

(C) The author(s) 2020. This publication is an open access article. 


\title{
STRATEGY OF IMPLEMENTATION OF THE CONCEPT OF THE NATIONAL PROGRAM OF MILITARY- PATRIOTIC EDUCATION «HORTING-PATRIOT»
}

\author{
Borodai Eduard Mykolayovych, getter of the Department of Pedagogical Mastery and Management \\ named after I. Zyazyun of Poltava National Pedagogical University named after V.G. Korolenko, \\ Poltava, Ukraine
}

DOI: https://doi.org/10.31435/rsglobal_ijitss/30122020/7290

\section{ARTICLE INFO}

Received 27 October 2020 Accepted 08 December 2020 Published 13 December 2020

\section{KEYWORDS}

concept, national program, military-patriotic education, Armed Forces of Ukraine, military formations, military service, Fatherland, defense of Ukraine, center for militarypatriotic education, subject «Defense of the Fatherland», pre-conscription training, military-patriotic education, physical development.

\begin{abstract}
The urgency of the proposed Concept of the national program of militarypatriotic education of children and students of Ukraine is due to: the need of the Armed Forces of Ukraine and other military formations to call up for military service citizens with a high level of moral, psychological and physical development; the lack in the state of an effective system of training citizens for military service and defense of the Fatherland, which can in a short time to restructure their activities in accordance with the requirements of the time; lack of a single scientific and methodological center for curriculum development, methods of preparing young people for military service, criteria for assessing military-patriotic education, lack of necessary educational facilities in secondary schools for pre-service training and military-patriotic education: low level of training for secondary schools in the subject «Defense of the Fatherland», which does not fully ensure the quality of teaching this subject. The purpose of the Concept is to create centers for military and patriotic education of children and students in all regions of Ukraine within the national system of training citizens for military service and defense of the Fatherland.
\end{abstract}

Citation: Borodai E. M. (2020) Strategy of Implementation of the Concept of the National Program of Military-Patriotic Education «Horting-Patriot». International Journal of Innovative Technologies in Social Science. 7(28). doi: 10.31435/rsglobal_ijitss/30122020/7290

Copyright: (C) 2020 Borodai E. M. This is an open-access article distributed under the terms of the Creative Commons Attribution License (CC BY). The use, distribution or reproduction in other forums is permitted, provided the original author(s) or licensor are credited and that the original publication in this journal is cited, in accordance with accepted academic practice. No use, distribution or reproduction is permitted which does not comply with these terms.

Introduction. In this difficult time for our society, when in different parts of the country there are manifestations of separatism, military aggression against Ukraine, it is absolutely necessary to strengthen the defense capabilities of the state, which can be built through: national-patriotic education of students at the national level. On the rise of the patriotic spirit of society, at a time when every Ukrainian woke up after a long sleep and defended his homeland, it will be important to create and provide conditions for the development of the National Educational Strategy for student youth «Horting-Patriot».

The priorities of this strategy are: patriotic upbringing from an early age, love for their homeland and their people, involvement of children and youth in physical culture and sports, sports selfdevelopment (self-defense skills, protection of family and friends), orienteering, primary care skills , moral stability in emergency situations, acquisition of qualities and understanding of the concepts of «friendship», «team» (teamwork), acquisition of skills in the use of training weapons and ammunition, personal protective equipment, fire training skills, climbing, passing the relevant areas with obstacles.

The purpose of the article is a theoretical substantiation of the National Educational Strategy «Horting-Patriot», a system of training future defenders of Ukraine.

Object of research: general and educational process of the National educational strategy «Horting-Patriot». 
Subject of research: the system of training high school students (grades 10-11) - future defenders of Ukraine.

Research results. At present, the issue of educating patriotism and forming the national consciousness of the population of Ukraine, which needs to be addressed at the state level, is becoming more important than ever. Particular attention should be paid to the patriotic education of students, which is currently one of the most important components of national security in Ukraine.

Horting is a promising area of military-patriotic education of youth in Ukraine today, which is becoming the foundation of the national spirit, philosophy and way of life of Ukrainians. This type of Ukrainian martial arts was created in 2008, thanks to the idea of masters, coaches and athletes who were involved in many martial arts represented on our planet and who promoted them.

The idea of horting is to form a comprehensive system of self-improvement of the individual, based on physical, moral, ethical and spiritual education, associated with the revival of ancient folk traditions of the Cossacks, passed down from generation to generation.

The education of patriotism during horting competitions is based on game technologies, which are one of the unique educational forms, which allows making interesting and exciting work of students. The excitement of the game provides a positive emotional color of standard monotonous activities, activates all mental processes and functions of the child. Another positive aspect of the game is that game technologies promote the use of acquired knowledge and skills in a new situation, so the material learned by students goes through a kind of practice, brings diversity and interest in the educational process.

To confirm this, we have the results of an analysis of a survey of students of secondary schools, which show that students prefer playful and competitive forms of military-patriotic education (national children's and youth military sports game «Horting-Patriot»-27.8\%, competitions in military applications sports $-23.2 \%$, participation in the military sports game «Falcon» («Jura») - 21.4\%).

The study of the essence of the National Children's and Youth Military Sports Game «Horting-Patriot» indicates its comprehensive nature as one of the means of patriotic, physical, psychological, mental and moral education of the younger generation, implemented based on crosscultural approach.

The essence of this game is to reflect in a child-friendly form of social relations of Ukrainian soldiers, theatrical performance of events typical of military training, combat operations. Education of schoolchildren by means of military sports game «Horting-Patriot» is a systematic and purposeful activity of the founders and management of the game, public authorities and public organizations to form in the participants of the game a high patriotic consciousness, loyalty to their homeland, readiness for civic duty to protect the interests of the Motherland. Therefore, the National Educational Strategy «Horting-Patriot» must have a clear systemic basis for its activities, namely:

- highly qualified trainers-teachers, horting instructors, who are narrowly engaged in the development of this field;

- annual calendar plan of events of different levels (all-Ukrainian, regional and oblast, city and district, local, school and group games), because only in competitions and struggles the real defenders of the Motherland are hardened and the team fraternal spirit is honed;

- uniform rules of competitions and comprehensive support of mass media at all levels, in all cities and regions of the country;

- good provision and staffing with specialized equipment needed for classes and events, namely: sports equipment, gymnastic mats, wrestling mats, liners, boxing bags, sports mannequins, training weapons, ammunition models, personal protective equipment, first aid kits and more.

When implementing the National Education Strategy «Horting-Patriot» it is necessary to provide students with knowledge at such a level that, if necessary, they become defenders of their homeland, because since childhood they have acquired the qualities of a courageous, strong, principled person who can stand up for himself and not afraid of any obstacles; by means of strategy she has acquired leadership qualities and by her own example can convince the people around her. Training physically strong, morally stable and patriotic citizens from an early age is a strategic goal in the development of our state, especially today, when we have no choice but to become even stronger.

Achieving a specific purpose requires a number of tasks:

- raising the status of military-patriotic education in Ukrainian society in general and in the education system in particular; 
- increasing the prestige of military service as a type of civil service and cultivating the attitude to the soldier as a civil servant;

- ensuring the establishment of centers for military and patriotic education of children and students at state, regional and local levels;

- ensuring the education of high patriotic consciousness in students, a sense of loyalty and love for the Motherland, concern for the welfare of their people, readiness to fulfill civic and constitutional obligations to protect national interests, territorial integrity and independence of Ukraine;

- increase and development of educational functions of general educational institutions concerning military-patriotic education of children and student's youth;

- effective use of national traditions taking into account modern world and domestic pedagogical experience and research of psychological and pedagogical science on military-patriotic education;

- ensuring the interaction of the education system with all social institutions to intensify the process of military-patriotic education of children and students;

- ensuring the formation educational, physical, psychological, social, moral and spiritual readiness for military service and encouragement to actively combat separatism, immorality, chauvinism and fascism;

- revival on a new theoretical and technological basis of the system of extracurricular and extracurricular military-patriotic education of children and students;

- promoting the promotion of military sports games such as the national children's military sports game «Horting-Patriot»;

- promoting the development of children's, students', youth and public organizations, centers and sports schools in the national sport of Ukraine - horting in order to develop and strengthen the physical, moral and spiritual health of children and students and the formation of future patriots;

- to create a psychological portrait of a modern defender of the Fatherland;

- to analyze the existing programs of physical and psychological training for students of secondary schools;

- to develop and implement a system of training future defenders of the Fatherland, starting with preschool education with the participation of leading specialists in education and sports;

- to develop a system of work with gifted students, which will contribute to the formation of key competencies of a successful serviceman, an officer of the Armed Forces of Ukraine and law enforcement agencies of the state;

- to create conditions for the comprehensive development of competencies for the defense of the Fatherland in students of secondary schools, both subject and design-technological, social, communicative, as important for further successful self-realization in military units, special units, sports and educational clubs, educational institutions Ukraine, etc.;

- to develop and test a new program on the Internet of the National Educational Strategy «Horting-Patriot» for students of preschool, secondary and out-of-school primary schools, taking into account the requirements of psychological research and age;

- to promote the qualification level of teachers and the preparation of their own pedagogical developments using modern programs of physical and psychological training, computer technology, means of promoting a healthy lifestyle, etc.;

- amendments to the state standards of complete general secondary education to ensure the integration of the subject «Physical Culture» with the subject «Defense of Ukraine» in a single branch «Military-patriotic education and physical culture» in order to improve the quality of military-patriotic education and physical training young people in secondary schools;

- transfer of teaching the subject «Defense of Ukraine» from 10-11 grades to 7-8 grades in order to increase the effectiveness of pre-conscription training and military-patriotic education of student youth.

The implementation of the National Educational Strategy «Horting-Patriot» and the system of military-patriotic education of student youth of Ukraine should be based on the following principles:

- the principle of national orientation, which provides for the formation of national identity, education of love for the native land, the Ukrainian people, respect for its culture, respect, tolerance for the cultures of all peoples inhabiting Ukraine; the ability to preserve their national identity, to be proud of belonging to the Ukrainian people, to participate in the development and protection of their state; 
- the principle of humanization of the educational process, which means that the educator focuses on the child as the highest value, takes into account its age and individual characteristics and capabilities, does not force its development, encourages independence, meets the basic needs of the child; develops an individual program of its development, stimulates its conscious attitude to their behavior, activities, patriotic values;

- the principle of self-activity and self-regulation, which promotes the development of the pupil's subjective characteristics; forms the ability to be critical and self-critical, to make independent decisions, gradually develops a civic position of the individual, a sense of responsibility for its implementation in actions and deeds;

- the principle of cross-culturality, which provides for the integration of Ukrainian culture into the European and world space, the creation of appropriate prerequisites for this; formation of openness, tolerant attitude to children and students to different from national ideas, values, culture, art, beliefs of other peoples; ability to differentiate common and different in different cultures, ability to perceive Ukrainian culture as an integral part of universal culture;

- the principle of social conformity, which necessitates the coherence of the content and methods of military-patriotic education to the real social situation in which the educational process is organized;

- the principle of historical and social memory is aimed at preserving the spiritual, moral and cultural-historical heritage of Ukrainians and reproduces it in reconstructed and modernized forms and methods of activity;

- the principle of intergenerational continuity, which preserves for posterity samples of Ukrainian culture, ethnoculture of the peoples living in Ukraine;

- the principle of Ukrainian ethnopedagogy, which is aimed at forming a Cossack-knight, a courageous citizen with a pronounced Ukrainian national consciousness and self-consciousness (Cossack worldview, philosophy, morality, character, ideology).

The concept of the National Educational Strategy «Horting-Patriot» provides for the passage of several stages of its implementation. Thus, at the initial stage it is necessary to agree on the Concept with all interested state executive bodies, to approve the Concept. To envisage the development of the state Program of military-patriotic education and training of youth for military service in the Armed Forces of Ukraine. Together with state authorities, educational institutions and local governments, envisage the development of standard regional programs of military-patriotic education and training of young people for military service, which would take into account the requirements for the regions on the organization of training for military service. In developing these programs, priority should be given to the most acute problems of the state of work on military-patriotic education in secondary, vocational and higher education institutions, typical for the region. These programs should be coordinated with public authorities and local governments. At the first stage, it is necessary to begin work on the development of standards (standard projects) for the placement of visual agitation in secondary and out-of-school educational institutions of Ukraine. Together with the mass media to start the development of military-patriotic programs and the publication of a textbook on world and Ukrainian experience in the organization of military-patriotic education. It is necessary to develop Regulations on centers of military-patriotic education and training for military service, to begin work on the formation of such centers. In the global Internet to develop active work to involve young people in military-patriotic activities using modern Internet technologies and communications.

Carry out work with secondary and out-of-school educational institutions on active involvement of pupils and students in military-patriotic education. Create a press center with the involvement of journalists who specialize in military-patriotic education and pre-conscription training of youth.

At the second stage to continue the implementation of measures for military and patriotic education. Based on the results of the implementation of the second stage, the development of pilot projects for the establishment of centers of military-patriotic education and training for military service in all regions of Ukraine is envisaged; association around the centers of military-patriotic education and training for military service of public organizations engaged in military-patriotic education of youth, development of organizational and legal scheme of their interaction; creation on the basis of the centers of military-patriotic education and preparation for military service, the allUkrainian network of search detachments; approval together with the departments of education, state authorities and local self-government of the state program of military-patriotic education and training of youth for military service; expansion of centers of military-patriotic education and training of young 
people for military service on the global Internet; completion of work on the creation of an allUkrainian network of centers for military and patriotic education and training for military service.

At the third stage, the establishment of centers for military and patriotic education and training for military service and the all-Ukrainian system of military and patriotic education of citizens with mass coverage of children and youth is expected to be completed. The main content and sequence of determining the results of the Concept include the following stages:

- drawing up a short plan of analysis of the state of military-patriotic education of children and youth and its results, development of methodical materials and documents for its carrying out, definition of the list of its most important directions, the most significant measures and problems which need to be carefully investigated;

- collecting information on the state of military-patriotic education of children and youth and its results, on the effectiveness of the measures taken, on the participation of both the organizers and various categories of children and youth;

- analysis of the effectiveness of the direct organizers of military-patriotic education, their performance of certain tasks, certain functional responsibilities, etc.;

- analysis and evaluation of the effectiveness of military-patriotic education with different categories, groups of youth. At the same time, both quantitative (number of events, level of coverage of participants, classification of activities by types, etc.) and qualitative indicators (effectiveness of measures, change of situation after their implementation, measures capable of providing the most formative, informational, mobilizing impact) are determined;

- determination of conclusions about the state of military-patriotic education of youth and its assessment, formulation of certain tasks and measures for its further improvement. They reflect: the general assessment of the state of military-patriotic education of children and youth and the achieved results, their comparison with the previous period (better, worse); the level of compliance of the work with the requirements, the problem to be solved, the available opportunities; advanced and lagging behind in the preparation and implementation of major activities; unused opportunities, means, omissions, shortcomings; priorities on which the main efforts should be focused.

The end result of the implementation of the National Educational Strategy «Horting-Patriot» is a positive dynamics of growth of military-patriotic education of youth in the country, growth of educational, physical, psychological, social and moral-spiritual readiness for military service and defense of the Fatherland and active counteracting separatism, immorality, chauvinism and fascism.

Conclusions. Summing up, we can say that the National Children's and Youth Game «Horting Patriot» is a game of brave, agile and friendly, a school of true patriots of Ukraine. Implementation of the strategy of the National Educational Strategy «Horting-Patriot» as an effective means of physical training, national-patriotic education of students, pre-service training is a necessary condition for creating an effective system of military-patriotic education of the younger generation and defense of the Fatherland.

\section{REFERENCES}

1. Bekh I. D. (1991). Kontseptsiia vykhovannia osobystosti. Ridna shkola. № 5. S. 40 - 47.

2. Bekh I. D. (1998). Osobystisno zoriientovane vykhovannia: nauk.-metod. posib. K.: IZMN. 204 s.

3. Bekh I. D., Chorna K. I. (2014). Prohrama ukrainskoho patriotychnoho vykhovannia ditei ta uchnivskoi molodi. K. 29 s. Yeromenko E. A. (2014). Khortynh - natsionalnyi vyd sportu Ukrainy: metod. posib. K.: Palyvoda A. V. 1064 s.

4. Elektronnyi fond bazy danykh Ukrainskoi Natsionalnoi Federatsii Khortynhu. Federatsiia tvoiei Batkivshchyny. Deklaratsiia ukrainskoho natsionalnoho vydu sportu khortynh. Informatsiina dovidka: vyd sportu - khortynh [Elektronnyi resurs]. - Rezhym dostupu: http://horting.org.ua/node/40239.

5. Saienko N. V. (2014). Pro dosvid i zavdannia patriotychnoho vykhovannia. Visnyk KhDAK. Vyp. 42. 